\title{
Review of Doug Selwyn (2019). All children are our children
}

New York: Peter Lang. 202 pp. ISBN 9781433161643 (Paperback)

\section{Caroline Green Whitcomb ${ }^{1}$}

Published online: 21 July 2020

(C) Springer Nature Switzerland AG 2020

Keywords Education $\cdot$ United States of America $\cdot$ Health $\cdot$ Inequality $\cdot$ Covid-19 $\cdot$ Solidarity

\section{An Incredulous Crisis}

The United States of America is in crisis. The pandemic continues to rage across the nation. Ongoing police violence, racism, psychotic statements by the president, and contradictory news sources have polarized the nation. Many Americans are, for the first time, coming to grips with the fact that we are not a great nation. I was born in the late 1970s to a family that prided itself on generational military service. I grew up believing this country is a Christian nation. A nation determined to protect the abused and exploited of the world. I recall the welcome home reception for my father after his tour in Saudi Arabia during the Gulf War. Surrounded by friends and family decked out in red, white, and blue, I remember holding back tears as the song, 'God Bless the U.S.A.' (Greenwood 1984) played through the speakers. It was not until I began my doctoral journey at the age of 39 that my beliefs about America began to change. As I read and listened to the voices of the nation's marginalized, my deep-seated patriotism began to wane and questions replaced once intrinsic beliefs.

Doug Selwyn experienced a similar awakening. Selwyn, a veteran of the public school system and a professor of education, had in his own words, 'a front-row seat to the train wreck' of American education (Selwyn 2019: 6). Written pre-pandemic in 2019, Selwyn recognized the disparity between what Americans want to believe and what was actually occurring at the local, state, and national levels. The disaster of education in the USA has been the subject of countless articles and books; however, Selwyn's (2019) All Children Are Our Children offers a fresh perspective. He guides his readers towards an honest understanding of the state of the nation by situating the

Caroline Green Whitcomb

cw10355@georgiasouthern.edu

1 Georgia Southern University, Statesboro, GA, USA 
[o]ngoing health crisis and the role that education plays within the larger picture of inequality, of the complex interplay of systems based on class, privilege, racism, sexism and on maintaining a status quo that serves those in power. (Selwyn 2019: 17)

In addition, Selwyn provides clear steps towards bringing safety, well-being, and health to our children. Amidst today's cries for change and the pandemicforced rethinking of education, Selwyn's articulation of the intentional weaving of societal evils for the ill of our children and his vision for a more just and equitable future make this work a necessary read.

For Selwyn, an understanding of US population health is necessary for understanding the failed educational system. Selwyn (2019: 17) quotes Jean Anyon: '[t]rying to fix an urban school without fixing the neighborhood in which it is embedded is like trying to clean the air on one side of a screen door.' His research unveils facts and statistics which counter the American perception that the United States of America is a benevolent, generous, Christian nation. The OECD ranks the USA 29th out of 35 countries in infant mortality, and yet the nation spends twice as much on per-person healthcare than the average of the other OECD countries. After rolling out pages of statistical truths, Selwyn (2019: 24) states, '[i]n the OECD the U.S. ranks $35^{\text {th }}$ out of $37^{\text {th }}$ in terms of poverty and inequality.' While the rest of the world may have a far clearer picture of the USA, nothing will change until Americans move beyond blind patriotism and see ourselves as we truly are. In a 2020 article, Selwyn continues this work, explaining US health and inequality in terms of the pandemic.

People living in poverty are more likely living in environmentally unsafe environments and are more likely to develop asthma and other respiratory diseases, heart problems, high blood pressure, and diabetes. They are most vulnerable to the virus because they are more likely to have these pre-existing conditions, more likely to have to keep working to feed their families, and less able to isolate at home. They may well be the people we are standing next to, or who are serving us. (Selwyn 2020)

Selwyn maintains the pandemic has highlighted the nation's health crisis, and Trump's attempt to eliminate the Affordable Care Act in the midst of a national catastrophe must be recognized by Americans as an epitome of historic cruelty.

\section{Chronic Stress and Children, an Evidence of Values}

Much of Selwyn's book is given to identify the issues which prevent students from receiving a liberatory, democratic education. The chapters focus on inequality, chronic stress, environmental factors, corporate capitalism, the purpose of education, high stakes standardized testing, and how we deny our children (Selwyn 2019). Selwyn's comprehensive explanation demonstrates how these are wreathed together, ultimately resulting in the continued oppression of the American subaltern.

Selwyn's weaving of practical solutions and examples of reform within his critical research sets this work apart. Selwyn describes Finland's educational 
transformation from a mediocre system in the 1960s to one of the world's best today. Currently, Finland's child poverty level is under $5 \%$, while the US is over $20 \%$. 'Every school has equally educated teachers and equivalent facilities, with equivalent resources, equivalent class sizes, and equal expectations for the education that each student will receive' (Selwyn 2019: 29). This is a sharp contrast to the US historic and present-day educational system which supports ongoing societal stratification. Finland's educational philosophy, based on the work of American theorist John Dewey, states: 'All pupils can learn if they are given proper opportunities and support, that understanding of and learning through human diversity is an important educational goal, and that schools should function as small-scale democracies' (Selwyn 2019: 29). Through Finland, Selwyn demonstrates there are alternatives if the USA is willing to change. Resisting an ivory tower critique, Selwyn's goal is not to catapult readers into a state of depression but to provide doable solutions that will hopefully ignite greater winds of change.

Selwyn's chapter on chronic stress is eye-opening, and when one considers the additional stress resulting from the pandemic and rise in racism, these truths become alarming. Selwyn's examination of the stresses experienced by the oppressed includes perceived discrimination, socioeconomic status and environment, efforts to adapt to the dominant culture, and daily and long-term poverty (Selwyn 2019: 49). In his discussion of the stress caused by high stakes standardized tests, Selwyn quotes a test booklet instruction manual.

A student who becomes ill and vomits on his or her test booklet or answer document and is able to continue the test should be given a new test booklet or answer document so that he or she can continue. Later, the student's responses and demographic information must be transcribed into the new test booklet...Do NOT return the soiled test materials to Pearson. (Selwyn 2019: 56)

Selwyn's response is perfect: 'What kind of people set up a system that assumes it likely that at least some students are going to be so upset by what they are required to do that they vomit? And I confess it was tempting to send dozens of bags of vomit-covered test booklets to the testing office.' (Selwyn 2019: 56) While the thought of shipping vomit-covered test booklets to Pearson probably brings a smile to the face of most educators, this example represents the heart of Selwyn's message. 'We present ourselves to ourselves and to the world as a society that values life, that values children, that values family. Our actions at the state and legislative levels do not come close to matching our words.' (Selwyn 2019: 6)

In chapter eight, Selwyn continues this vein of thinking by discussing the ways we deny our children language, culture, point of view, the reality of maturation and development, play, the fact that people learn differently, and hope.

When everything is determined by others, from what is studied, to how it is studied, to when it is studied and the pace of that study, and then how it is assessed, students learn that their voices, views, and values do not matter. And when they are denied their language, their culture, their history, their interests, 
and their voices, it becomes clear that the only meaning they can make it is that they don't matter. (Selwyn 2019: 130)

\section{What Can Be Done?}

The USA is in a state of disarray, and we are desperate for a new vision, a vision we can all be proud of. To this, Selwyn asks and answers, 'What can schools do?' (Selwyn 2019: 132). He offers specific advice to teachers and advice to society at large. Many of his suggestions are based upon personal experience, the changes he made in his classroom, and teaching which proved transformative. Selwyn focuses on relationships. 'Everyone I spoke with and everything I read places relationships as the most significant of the factors that make it possible for students to be healthy, happy, and academically successful' (Selwyn 2019: 134). He posits relationships must extend outside of the teacher/student relationship and involve families and the community. Advisory systems are critical in middle school and high school as students move from one teacher to many. Relationships are key, not only in the educational setting but at large. Empathy grows as we become intimate with those labeled different from ourselves.

In regard to society, Selwyn suggests building free healthcare clinics adjacent to schools, connecting schools with the farming community, backpack programs, extending recess, and P.E. and all while providing opportunities to grow and learn. 'Schools are places in which students can further their understanding of how and why systems intersect and why those systems have an impact on their lives' (Selwyn 2019: 160). In the final chapter, Selwyn reminds readers that neutrality is a political act. Interestingly, he highlights the Black Lives Matter movement in Seattle's schools in 2016. While Selwyn primarily focuses on the roles we must play at the school and community level, he also offers some insight into what must also take place at state and national levels. Today, as we stumble towards the coming elections amidst heightened racism, horrific killings, protests, and the continual rise of Covid-19 cases, Selwyn's calls for solidarity, active citizenship, and critical thinking are all the more necessary.

While writing this review, I had the opportunity to seek Selwyn's current perspective on the state of the nation. For Selwyn, the United States of America is in a different place than it was just 3 or 4 years ago. Today, city officials, school boards, administrators, and educators have the historic opportunity to question who we are, what it means to educate, how we define curriculum, and how we create a more just educational system for our children. For once, the status quo will not work, the pandemic has forced educational change. The question now becomes what will teachers do and what will we do with this opportunity? With a clarion call, Selwyn's book concludes: 'We have a choice to make, about whether to allow ... greed and ... lust for power and profit to continue to destroy our health and our democracy, or whether we will stand and say no to them and yes to our health and well-being, and to our children' (Selwyn 2019: 194).

I have only one critique of this work, the cover. In Creole (2013), Stephen Cosgrove, an American children's book author, writes, '[n]ever judge someone by the way he looks or a book by the way it's covered; for inside those ... pages, there's a lot to be discovered' (Cosgrove 2013: 34). Do not judge a book by its cover, sage advice. I have to admit I judged the humdrum cover and in so doing nearly missed out 
on a book every American educator should read. Through Selwyn's All Children Are Our Children (2019), we have been given a fresh glimpse into the hidden aspects of our societal ills and an opportunity to evoke true change. Read the book, heed the wisdom, implement the solutions, and do not let the cover stop you.

\section{References}

Cosgrove, S. (2013). Creole. Clovis: Price Stern Sloan, Inc..

Greenwood, L. (1984). God bless the U.S.A. [song]. Nashville, TN: MCA Nashville.

Selwyn, D. (2019). All children are our children. New York: Peter Lang.

Selwyn, D. (2020). Covid 19 reveals underlying truths about our society. Greenfield Recorder, 14 April. https://www.recorder.com/my-turn-selwyn-COVID-19RevealsUnderlyingTruths-33758887. Accessed 26 June 2020. 